\title{
Politics-administration interface: the case of the city of Cape Town
}

\author{
Robert Cameron
}

\begin{abstract}
This article is an analysis of a controversial policy decision on the part of the newly elected Democratic Alliance local administration in Cape Town, South Africa, to fire senior officials of the previous African National Congress administration and to introduce an interim policy for senior managers that stated that such positions should be filled by people who are 'politically suitable and acceptable' to the ruling party. The author of this article was part of a team that reviewed this policy. This article is an account of this process.

The author developed, on the basis of comparative experience, a heuristic model that could serve as the basis for gauging the extent of politicians' involvement in the appointment of staff. A continuum illustrating the different approaches to council appointment of staff was generated. Five different approaches were identified, namely neutral, minimalist appointment of senior staff, appointment of top and middle-level staff, large-scale appointment in all ranks and fusion of party/state. The report concluded that the most appropriate of these models is the minimalist appointment model whereby councillors should have the right to appoint certain selected senior staff.
\end{abstract}

\section{Introduction}

Defining politics-administration relationships has been a constant debate amongst administrative theorists since the days of Woodrow Wilson. This article is an analysis of a controversial policy decision on the part of the newly elected Democratic Alliance (DA) local administration in Cape Town, South Africa. One of the first steps that the administration took was to fire senior officials of the previous African National Congress (ANC) administration and to introduce an interim policy for senior managers that stated that such positions should be filled by people who are 'politically suitable and acceptable' to the ruling party.

The author of this article was part of that policy process. He was contracted by the City of Cape Town as a consultant first to write a paper looking at international best practice in this regard and second, to chair a committee that reviewed the policy as a whole. This article is an account of the process. It begins with a discussion of the changing local government context in South Africa. This

Robert Cameron is an Associate Professor in the Department of Political Studies, University of Cape Town, South Africa. CDU: 711.4

International Review of Administrative Sciences [0020-8523(200303)69:1]

Copyright (C) 2003 IIAS. SAGE Publications (London, Thousand Oaks, CA and New Delhi), Vol. 69 (2003), 51-66; 032767 
is followed by an examination of this controversial appointments policy of the City of Cape Town. An analysis is undertaken of the theoretical and comparative literature on politics-administrative relationships. A heuristic model was developed in this regard to guide the review of the policy. The final part looks at the policy recommendations of the Committee of Inquiry which led to a change in policy.

\section{History of local government in South Africa}

Prior to 1994, South African local government was structured on racial grounds, although only white municipalities were proper, functioning entities with sufficient sources of revenue. South Africa had inherited the English system of local government. Under this system the Town Clerk was the Head of the Administration and other heads of departments, depending on the size of the town, supported him/her. They, together with their supporting staff, were supposedly only responsible for the administration and carrying out policy of the Council.

Because councillors were mostly laypersons in municipal affairs, they relied heavily on the advice and guidance of the Town Clerk and heads of departments. Officials often played a disproportionate role in policy formulation (Cameron, 1986). The extent of councillor involvement in policy often depended on the quality of leadership in council. There was also little party-political affiliation at local government level (with the notable exception of Johannesburg) (Craythorne, 1990).

\section{Local government transformation process}

The 1990s saw the negotiation of a new constitutional system in South Africa at all three levels of government. An agreement was reached during constitutional negotiations amongst the major stakeholders, most notably the then ruling party, the National Party (NP) and the ANC, to restructure and deracialize local government in three phases:

- Pre-interim phase. This phase covered the period from the passing of the restructuring legislation in February 1994 until the first local government elections held in 1995/6.

- Interim phase. This phase started with the first local government elections and ended with the implementation of the final constitutional model of local government in 1997 (although power-sharing arrangements remained in effect until 2000).

- Final phase. This phase began with the final constitutional model of local government in 1997, although some of the constitutional provisions only took effect after the 2000 local government elections (Cloete, 1995).

South Africa's first democratic local government elections took place in $1995 / 6$. These elections also introduced party politics openly into local government. There were caucuses in most municipalities in the country. There were attempts to increase the policy-making powers and reduce that of officials during 
the interim phase although the power-sharing mechanisms tempered the full effect of party politics.

A two-tier system of local government was introduced into metropolitan areas. In the Cape Metropolitan Area (CMA), the wealthiest and most resourced of the metropolitan local councils, the Central City of Cape Town, was won by the ANC. Party politics became a dominant feature of the CMA area. In the CMA elections, only seven independent candidates were elected in the 172 wards.

The final phase of local government made provision for stronger executive authorities. The key reasons advanced for stronger executive authorities were:

- The ability of mayors to run cities efficiently and innovatively and not be tied down by bureaucratic red tape. This was of particular significance, given greater globalization where cities are seen as arenas for economic competition in the global market place. Executive mayors could play a key role in attracting investment.

- The need for mayors to be high-profile public figures which should clarify accountability and heighten interest in civic affairs (Cameron, 2000).

The Municipal Structures Act also made provision for two types of executives in cities, namely the Mayoral Executive System and the Collective Executive System, with some executive powers being vested in the Mayor in terms of the former model and in the Executive Committee in the latter one. It was the responsibility of the Provincial Minister of Local Government to choose the option his/her party wanted. In the Western Cape the Collective Executive model was chosen. Although Cape Town does not have an Executive Mayor model, the Collective Executive system also makes provision for a strong executive (Republic of South Africa, 1998).

This legislation is in line with global trends in many countries that have moved towards stronger executives at local government level (Wilson and Game, 1998). There is now more executive councillor influence in policy formulation and less ordinary councillor involvement in policy and administration. This has led to gaps developing between executive councils and ordinary councillors. It also means that these executive councillors play a much greater role in policy formulation. Conversely, the policy formation role of officials has been reduced substantially.

\section{Cape Town 2000 - Democratic Alliance control}

The Municipal Structures Act made provision for single-tier authorities (megacities) to replace two-tier authorities in metropolitan areas. The newly formed DA won a comfortable majority of seats on the new uni-city winning 107 of the 200 seats. The DA and ANC won all the wards between them as well as 92 percent of the seats. Smaller political parties, through proportional representation vote, won the rest of the seats. The eclipse of independent candidates finally occurred with not one independent candidate being elected.

With no forced power-sharing mechanisms to facilitate consensus and the final demise of independents, the full blast of party politics at local government level 
descended upon Cape Town for the first time. The newly elected DA had not only won control of the new Cape Town unicity; it had also wrestled control of the crown jewel component of it from the ANC, the erstwhile City of Cape Town. Not only was it going to implement its electoral mandate, it was also going to reverse some of the ANC's local government policy. The first target in this regard were senior officials of the previous ANC administration.

\section{Democratic Alliance's appointment policy}

The DA came out with a policy approach to political appointments in local governments that it controlled on 10 January 2001 (Democratic Alliance, 2001). This was intended to be an interim policy outlining the reasons why certain positions in government administrations should be filled by people who are 'politically suitable and acceptable' to the ruling party.

The document stressed that the DA believed in a clear separation of party and state. It stated, however, that there are certain positions in government administrations that are, by definition, politically sensitive and not simply bureaucratic in nature. These positions tend to exist in two broad fields: strategic management and communication. In both categories incumbents need to have not only the relevant skills and qualifications but also 'a deep commitment to the policy programme of the ruling party'.

The document also argues that a clear, rational and public distinction should thus be made between positions that simply require appropriate skills and qualifications. The criteria for posts that require political suitability can be defined as any post

- which involves the development of government policy at a strategic level ensuring alignment with party political objectives and programmes;

- which requires the incumbent to be trusted with sensitive and/or confidential party political information; and

- which requires the incumbent to direct, at a political level, government communication.

The document concludes by stating that because political suitability is necessary for certain positions, incumbents in these positions should not be employed on the same terms as ordinary public servants. Rather, they should be employed:

1. on contract, without the benefits of public servants in permanent positions;

2. for a period not exceeding the date of the next election; and

3. only if they are demonstrably qualified in all respects to do the job.

The flip-side of this policy was that senior officials who were not "politically suitable and acceptable' were unlikely to find senior positions within the new DA administration. Accordingly, six senior officials - five from the City of Cape Town, including its Senior Manager and one from Tygerberg — had their contracts terminated by the DA administration after negotiations to find them alternative positions with the administration broke down. 
This policy was further developed by the then DA adviser, Ryan Coetzee, in an article in The Argus newspaper on 19 February 2001. He stated:

Political parties are elected on the basis of a manifesto, and are required to implement their manifesto. In order to do so, the top officials responsible for turning the party's policy into government programmes need to support the objectives of the policy, be trusted with confidential party information, attend party caucuses and be relied upon to keep the content of discussions that take place at these caucuses confidential.

He went on to say: 'Similarly, the official in charge of communication needs to endorse enthusiastically the ruling party's programme in order to communicate its implementation convincingly'.

There was a major political reaction to this policy with the ANC, in particular, being outraged by this decision to terminate the contracts of their erstwhile senior officials, demanding that they be reinstated. The ability of the DA to implement this policy was accentuated by the fact that the ANC had declined to accept the positions on the Executive Committee to which they were legally entitled.

This policy was also attacked in the press on the grounds that it was politicizing the city administration. Most significantly, it caused strains in the ruling DA administration. The DA had been formed just before the 2000 municipal elections and its main constituent elements were the conservative National Party (NP) (which ruled the country from 1948 until 1994) and the more liberal Democratic Party (DP). Elements within the old DP were opposed to this perceived politicization of the administration, particularly since they were criticizing the ANC at national level for doing precisely the same thing, namely appointing political supporters to senior government posts.

As a result of the public outcry and the tension within the DA, the author was commissioned to undertake a comparative analysis of senior staff appointment policy at local government level. This report undertook an analysis of the theoretical and comparative politics-administration literature which is discussed hereunder.

\section{Relationship between politics and administration}

The classical viewpoint of the relationship between politics and administration is that of Woodrow Wilson, who argued that there should be a clear distinction between these two spheres. Politics is concerned with the 'role of public opinion, the activities of political parties, the function of legislative bodies . . . the clash of opinion and the conflict of values' (Waldo, 1968: 147). Administration was regarded as the neutral implementation of policy by bureaucrats in a non-partisan, technical fashion. This is sometimes called the master-servant relationship. At local government level this would mean that the council issues orders and the officers carry them out. The function of policy formulation should be that of the politician, while policy implementation should be the domain of the administrator. This enables civil servants to be appointed on the basis of merit and not nepotism. One of the defining characteristics of Weber's model of bureaucracy was that civil servants should be selected on the basis of merit and competence rather 
than ascriptive criteria such as caste, race, class or language. One of the reasons for the adoption of merit recruitment in western countries was the desire to remove the appointment of administrative positions from political patronage (Peters, 1989: 75-6). The civil services of most western countries are based on this doctrine, which also underpins the councillor-officer relationship at local level.

Wilson's views are sometimes more complex than he is given credit for. He was concerned with both the corrupting and politicizing interference of party organizations in administrative affairs and also with the extensive attention by Congress to administrative matters. When Wilson was suggesting a clear differentiation between politics and administration, he was attempting to strengthen and redirect the legislative function while protecting the administration from political interference (see Svara, 1998). It was later writers who introduced this rigidity between politics and administration.

The most serious criticism of the politics/administration dichotomy came from Waldo in The Administrative State in 1948. He argued that the emphasis on expert judgement and scientific knowledge created a government in which the elected politicians had little role in decision-making. He argued that bureaucrats were becoming too loyal to the profession rather than the public (cited in Cox et al., 1994: 9-11).

Waldo introduced the concept of administrative politics. The argument is that a rigid distinction cannot be made between public administration and policymaking or policies. It is advanced that public administration is policy-making (also see Adamolekun, 1986: 14). This politics-administration distinction has long been recognized by administrative theorists as an artificial one. Bureaucrats often have technical expertise and detailed knowledge of their various fields; they are often more informed than politicians and this gives them the authority to make detailed policy decisions. A high degree of politicization exists, even in western countries, in the appointment to higher civil service posts. Bureaucrats often pursue their own interests, empire building being a common goal. At local government level senior officials not only have professional training and experience; they have a commitment to the service whether it be in health, engineering or local economic development. They will submit reports and ideas to councillors, in particular committee chairmen, and in so doing strongly influence policy. In addition, conversely, elected politicians are often engaged in what would ordinarily be described as administration or management (Byrne, 1986: 176-7; Smith, 1988; Wallis, 1989; Harris, 1990).

A study of the then Cape Town City Council in 1986 (Cameron, 1986) revealed a number of ways that bureaucrats influence policy. First, through their control of the agenda they can ensure that a number of issues never actually end up on the agenda; second through the cluttering of the agenda with trivia so it is difficult to distinguish the wheat from the chaff; and third, they are able to prioritize reports (depending on whether they want issues to receive urgent attention or die a slow death). 
Also, the field of implementation studies has shown that bureaucrats can often alter or even negate the intention of policy-makers when they are implementing policy.

The tacit refusal to implement a policy or programme is good example. As Peters (1989: 280) puts it, non-administration is difficult to control. It is considerably harder to get the bureaucracy to do something that it is not (yet should be) doing than to stop it doing something it should not be doing.

Lipsky (1980) portrays lower-level bureaucrats as street-level bureaucrats and argues that they make policy carrying out a political role, determining the allocation of particular goods and services in the society. The important point is that it is not only senior bureaucrats who make policy.

Finally, the idea of the neutral administration has also been heavily attacked from the left. Neutral appointees may also be apathetic if not hostile to programmes. Bureaucrats are seen as a part of the ruling elite class who use their control over access to these resources to benefit this class generally (Smith, 1988).

Merit appointments do, however, have some disadvantages. Merit appointment implies a value-free bureaucrat who will administer public policies regardless of their impact on society. Individuals elected by patronage (spoils system) are more likely to be disposed towards the programme of a political party in power than the supposed neutral appointees of a merit system who may be apathetic, if not hostile to that programme. Peters (1989: 76) suggests that a committed bureaucracy requires that political appointees be selected for a combination of political disposition and administrative talent, rather than for political views only.

Having said that, in effect all political systems have some political appointments (often euphemistically called policy-making positions). In the United States and several continental European countries there are a large number of political appointees, while in Britain there are relatively few.

Another issue is whether politics ought to be separated from administration. The Soviet Union was an example of a local government system which fused politics and administration. From at least Khrushchev's tenure until the late 1980 s, there were repeated attempts to decentralize powers to local government. These failed not only due to the principle of hierarchical subordination but also fundamentally due to the 'leading role' of the party. Local governments were required to obey both state and party structures at the next hierarchical level.

Elected representatives met rarely and did little other than rubber-stamp decisions of the executive. The executive itself was controlled by the party. Many senior administrators and a high proportion of elected representatives were party members. In fact Article 6 of the Constitution guaranteed the party's leading role.

However, the party line was not necessarily consistent and clear. There was a high degree of local independence, particularly during the latter days of communist rule, when local party bosses could pursue their own ideas (Coulson, 1995).

This model of fused politics-administrative relationships took on a particular form in developing countries in the 1960s and 1970s.

At one time there was a strong belief that civil services in developing countries 
should be politicized. Politicization of the administration operated at two levels: internally and externally. Internally, the administration became politicized when recruitment for, and continuance in, positions of responsibility were solely the preserve of party members. Externally, it occurred when the administrative services were unable to act without the consent of the unit representing the party (Bola-Ntotele, 1986).

While most ex-British colonies adopted their mother country's form of administration, they rejected the idea of civil service neutrality. In Francophone Africa, following the lead of their colonial power, politicized administration was a matter of course (Subramaniam, 1990: 396).

What were the reasons for this? First, the new ruling parties often found themselves with large mass support but poorly integrated mobilization for stable economic tasks. They accordingly used every means at their disposal for this purpose, including the civil service. This was more pronounced in one-party states, where politics in the sense of policy determination was the business of the party, which belonged to everyone. The execution of policy by the civil service demanded mobilization of popular support for the party policy, which was a political function. This combination of executive skill and support-winning tactics postulated a simultaneously politicized and skill-based civil service. At the minimum the oneparty state demanded civil service loyalty to the party's ideology, if not active support.

Another widely used argument was that of saving talent. The separation of political and administrative offices assumed the availability of educated and talented people to fill both offices. It was argued that because trained manpower of both types is in short supply in Africa, complete transferability between both types of offices seemed desirable and possible. It was also held that participation in politics reduced the opportunities of civil servants to sabotage these politics. Participation in politics increased policy acceptance. This fusion of policy and administration occurred at both central and local level in a number of countries, including Tanzania and Zambia (Subramaniam, 1977, 1990; Mphaisha, 2000).

While this final model recognized that the politics-administration distinction was obsolete and that administrations are inevitably partially politicized, this was no justification for introducing a totally politicized civil service. The African experience has shown that bureaucratic corruption and maladministration results from the fusion of politics and politicization of administrative systems. First, the exercise of political control over the administration restricted the selection base of candidates, since only party members or their nominees were put up for recruitment. This reduced the chances of building up a skilled staff of administrators loyal to the department. This led to accountability to political leaders rather than to the general public. Activities that promoted the welfare of the population were relegated to secondary concerns. In order to gain approval of superiors, public servants often glossed over or ignored any reference to real problems and the concerns and needs of clientele.

Second, the effects of this politicization on the population were that it acted as 
FIGURE 1

Politics-administrative continuum council appointment of staff

\begin{tabular}{|c|c|c|c|c|}
\hline Neutral & $\begin{array}{l}\text { Minimalist } \\
\text { appointment }\end{array}$ & $\begin{array}{l}\text { Medium } \\
\text { patronage }\end{array}$ & $\begin{array}{c}\text { Comprehensive } \\
\text { patronage }\end{array}$ & $\begin{array}{l}\text { Party-state } \\
\text { fusion }\end{array}$ \\
\hline $\begin{array}{l}\text { Neutral. } \\
\text { No member } \\
\text { of staff } \\
\text { replaced } \\
\text { by new council } \\
\text { (e.g. parts of } \\
\text { United } \\
\text { Kingdom) }\end{array}$ & $\begin{array}{l}\text { Minimalist } \\
\text { appointment } \\
\text { of senior staff } \\
\text { (e.g parts of } \\
\text { United } \\
\text { Kingdom and } \\
\text { United States, } \\
\text { France, } \\
\text { Germany) }\end{array}$ & $\begin{array}{l}\text { Appointment } \\
\text { of top and } \\
\text { middle level } \\
\text { appointments } \\
\text { (e.g. Latin } \\
\text { America) }\end{array}$ & $\begin{array}{l}\text { Large-scale } \\
\text { appointment } \\
\text { in all ranks } \\
\text { (e.g. USA in } \\
\text { 1920s and } \\
\text { 1930s) }\end{array}$ & $\begin{array}{l}\text { Fusion of party/ } \\
\text { state. Need to } \\
\text { belong to } \\
\text { political party } \\
\text { (e.g. Soviet } \\
\text { Union, Zambia, } \\
\text { Tanzania) }\end{array}$ \\
\hline
\end{tabular}

an incentive to support the dominant party. It relegated a section of the population to a marginal role. Non-party members with no personal influence found it difficult to get access to public administration; more importantly, they were excluded from positions of responsibility (Bola-Ntotele, 1986).

\section{Models of politics-administration relationships}

What specific lessons were there from the international literature for the City of Cape Town? First, any attempts to introduce a policy based on a rigid politicsadministration distinction would be conceptually unsound and naïvely presume that officials play no role in politics, and could well cause policy problems for politicians at a later stage. Having said that any attempt to fuse politics and administration through having a totally politicized administration would lead to bureaucratic corruption and maladministration. The question then was to try to find some middle ground between these two positions.

The report attempted, on the basis of comparative experience, to develop a heuristic model that could serve as the basis for gauging the extent of politicians' involvement in the appointment of staff (Cameron, 2001; see Figure 1).

In the figure, a continuum illustrating the different approaches to council appointment of staff was developed. On the one end of the continuum is the neutral model. This reflects the artificial politics-administration distinction by assuming that senior staff are non-partisan and not involved in policy. An example of this model would be a traditional British local government model (which is slowly being eroded). Senior staff are being appointed by government at both national and local levels (Halligan, 1997).

The next model is mayor/council appointment of senior staff, namely the minimalist appointment model. A new council may feel that senior staff were too closely associated with the previous order and need to be replaced by officials it can trust. This model is typically found in many Western European countries such 
as France and Germany, parts of the United States and even now in Britain (Gunlicks, 1986; Keating and Hainsworth, 1986; Norton, 1986; John and Cole, 1999).

The third model is mayor/council appointment of both senior and middleranking staff, viz. the medium patronage model. This would be the Latin American model where not only are senior staff replaced, but so are middle management such as divisional heads. As opposed to the minimalist council appointment model that would typically consist of the replacement of 6-12 senior staff, the council appointment of senior and middle-ranking staff could involve around 5 percent of total staff. There is much patronage associated with this model (Nickson, 1995).

The fourth model is the comprehensive patronage model. When there is a change of administration, whole-scale purging of the organization occurs from the highest to the lowest levels. An example of this was the powers that directly elected United States mayors had in the 1920s and 1930s to dispense large-scale patronage by firing officials of the old order and replacing them with their own employees, as a way of settling favours and promoting new client-local relations (Svara, 1985).

The final model is the one that can be termed the fused party-state model whereby the interests of the local government become indistinguishable from that of the political party. This was found in one-party states such as the Soviet Union and in some third world countries and typically mean that a large number of staff would only be employed or promoted if they belonged to and promoted the interests of the party. The party itself was involved in the recruitment of local government staff (Adamolekun, 1986; Coulson, 1995).

The one difference between this model and the patronage one is that the latter is based on clientelism and personal networks. The fused party-state model demands greater ideological purity and loyalty to the state rather than personal loyalty to an individual mayor. Arguably, in the latter days of soviet rule the fused party-state resembled the comprehensive patronage model though a network of powerful mayors. One can still, nevertheless, draw a conceptual distinction between these two models.

The report concluded that the most appropriate of these models is the minimalist appointment model whereby councillors should have the right to appoint certain selected staff.

\section{The Committee of Inquiry}

This comparative report was favourably received by the Executive Committee (Exco). It confirmed that there was international precedent for councils to appoint staff although there was recognition that the Council has blundered in the communication of this policy - in particular the use of the term 'political suitability and acceptability' was considered inappropriate.

The second part of the investigation involved the setting up of a Committee of Inquiry to review the policy as a whole. An independent review body, which was 
chaired by this author, was set up to recommend whether this interim senior appointment policy should be maintained, reviewed or rescinded. The Committee met in April 2001 and interviewed a number of councillors and officials, as well as representatives of professional local government associations.

The policy question was to what extent should a South African local government council be able to replace staff of the old political order and on what basis? The committee used the Cameron comparative continuum as its starting point (Commitee of Inquiry, 2001). It recognized that senior officials have important policy-making and oversight responsibilities that are essential to the strategic focus of the Council and its Exco. Elected politicians need, therefore, to have the trust of senior officials whose responsibilities include the strategic planning of policy and advising Exco on the difficult policy choices available to the Council in order for it to work harmoniously and efficiently.

This was the principle of democratic, good governance. If the senior officials do not have the trust and confidence of the elected (majority) of the Council, or they stand in the way of the programme and mandate of the Council, then the wishes of the electorate may be defeated or compromised. Put another way, the elected politicians should have the power over policy - not the officials. Officials whose philosophical and ideological approach contradicts those of the politicians may find it impossible to embrace the vision and values of the elected politicians and may even willingly or unwillingly obstruct.

This was the committee's first principle of good governance: the Principle of Confidence.

The Committee examined the comprehensive patronage model and the fused party-state models and came to the conclusion that it is not in the public interest for there to be the wholesale sort of purge of personnel that either model contemplates. It was felt that it would not suit the political and cultural character of South Africa, and it would not find much or indeed any support from the citizens of Cape Town or the personnel elected or employed to serve in its Council.

In particular it breached what was identified as the Principle of Continuity. Used predominantly to defend notions of a 'neutral', 'professional' civil service, continuity in personnel in the civil service allows the 'show to go on', detached from political change arising from electoral upheaval.

The Committee argued that a properly constructed policy, supported by a code of conduct that has attracted broad cross-party support would, if implemented properly, help ensure that there is no repetition in the future.

The Committee believed that there was a third starting principle: the Principle of Competence. By competence it was meant that the individuals appointed to all positions within the Council must be worthy of the appointment. This ensures that the element of merit and professionalism is maintained. In other words, no person who would otherwise not have got the job should be appointed to a senior position simply because he or she meets the confidence criterion.

The Committee believed that this would help ensure that the question of confidence operates 'downwards' as well as 'upwards'; subordinate members of staff 
are entitled to have confidence in their senior managers. Above all else, officials should have confidence that senior managers are in position because of their abilities and not because they are loyal to the ruling party.

It was argued that there is a hierarchy of principles: the principles of confidence and competence are absolute, 'non-negotiable'. The principle of continuity, though important, may be eclipsed by one or both of the first two principles.

\section{Findings and recommendations}

The major findings of the Committee of Inquiry (2001) were:

- The world of local government is changing fundamentally in Cape Town. Greater party politicization and a move towards stronger executives are redefining the traditional politics-administration relationship irrevocably. There is a move towards stronger councillor and less bureaucratic involvement in policy formulation, a trend that will accentuate during the next five years.

- Many officials are understandably uneasy and, in some cases, do not fully comprehend this changing politics-administration relationship which is reducing their traditional role in policy formulation. However, resistance to change is a natural phenomenon in organizations and is something that needs to be managed.

- Notwithstanding this, the Committee felt that the interim policy was ambiguous and led to confusion, insecurity and malaise amongst many officials. Despite assurances by the acting Municipal Manager to the contrary, there was a widespread perception that political suitability and acceptability would be an overriding factor in the determining of positions in the unicity.

- The brief of the Committee was to examine whether the interim appointment policy should be retained, abolished or modified. The retention option was rejected. The Committee found that the current policy was ambiguous, confusing and had affected staff morale. The impression had been created that partypolitical suitability would be the major criterion for a senior position, which was found unacceptable.

- The abolition option was also rejected. Given the greater party politicization of local government, the Committee found it naïve to think that politics plays no role in the bureaucracy. Senior officials contribute to policy and affect the impact of its implementation.

- The recommended option was that the existing policy be modified and that each incoming council should have the right to choose certain selected posts. Beyond the confidence that every employer should have in its employees, the Committee accepted that in modern government there is a need for the elected representatives to have full confidence and trust in the senior officials charged with the responsibility of making policy and advising the elected representatives on the policy choices they face.

- Defining, in objective terms, the exact nature of these positions was not an easy undertaking, and while the overwhelming majority of the people the Committee interviewed agreed with the concept and with the underlying proposition 
that an added component of confidence and trust was needed in these category of posts, none could offer much help in terms of the precise definition.

- However, while there were differences of emphasis, the following proposition found favour with the overwhelming number of Exco members and past and present officials that the Committee talked to: that ordinarily there would be the positions

(a) where an inherent part of the post-holder's authority and responsibility concerns matters of policy-making at the highest level;

(b) that these are strategically vital for the effective planning and implementation of the government's policy mandate; and

(c) that in most cases this will be the senior line function position/head of department, where there is a direct interface with the political tier (the elected representatives) and who, therefore, works closely with the elected representatives in making decisions around policy choices and provides advice in relation to those decisions.

- This rationale, this set of objective criteria, was in the Committee's opinion a long way away from the notion of a 'politically sensitive' post, with all the inferences about party-political allegiance that this provoked. For this reason, and in order to underscore the point, the Committee proposed that senior appointments requiring the application of the principle of confidence be named as Strategic Policy Appointments, and 'ring-fenced' accordingly pursuant to written Strategic Policy Appointments Policy, supported by a Code of Conduct for Strategic Policy Appointments.

- Evidence that the Committee received from both Exco members and senior Council officials confirmed that the recent changes of government had caused uncertainty, instability in the Council's most senior officials and, to a very large extent, paralysis. It was felt that a properly constructed policy supported by a code of conduct that has attracted broad cross-party support would, if implemented properly, help ensure that there is no repetition in the future.

- While the Committee recognized that the exact number of such strategic policy appointments would vary from one government to another, it felt that the positions should be clearly designated as such, in order that candidates for appointment are aware of the additional considerations that apply and in order that the rest of the Council staff are also clear in their minds.

- The policy and the code of conduct shall state categorically that appointment to a strategic policy position does not in any way compromise or dilute the duty of the official to serve the whole Council, and through the Council, the interests of all of the citizens and communities of Cape Town. Once appointed, a strategic policy appointee should implement policy in a non-partisan way.

- It followed from this that Strategic Policy Appointments should not be exempt from the Council's overall obligations under the Employment Equity Act (which embodied affirmative action policy) and its own commitment to diversity at all levels of the Council Staff. A commitment to the service of all the peoples 
and communities of Cape Town should remain a requirement of all officials of the Council.

- It was recommended, however, that Strategic Policy Appointments should receive separate contracts of employment with limited terms, linked to the life of the existing Council (with a new council having the option of extending this for up to two months, for purposes of continuity during the transition). The terms and conditions of the contract shall recognize the limited contractual duration and, ordinarily, will attract higher remuneration accordingly.

- The Committee was of the view that it is not possible or desirable to suggest a definitive number of such positions because it will vary from government to government, depending on the priorities, ideology and mandate of the particular government. Certain positions, such as the City Manager, his or her deputies, and the senior communications person(s) would constantly fall in this category, but others may not. What is a strategically vital position to one government may not be so for the next. It was also felt that these posts should be limited.

- Finally, it was noted that the recommendations were offered as a package Strategic Policy Appointments cannot succeed unless

- there is broad consensus, across parties, of the principles of good governance that inform the conceptualization of the modified policy;

- that the consensus should, in turn, inform the writing of a detailed policy based on the propositions outlined earlier;

- it is supported by a Code of Conduct to govern the conduct of the Strategic Policy Appointee; and

- with an appropriately re-crafted set of employment contracts for such positions.

- Accordingly, it was recommended that the Council fully workshop this report, and its findings and the recommendations proposed, with the whole of council, in order to build up knowledge, expertise and consensus in the process and in the policy itself.

This policy was accepted by Exco in June 2001. It also affirmed that the posts affected by the policy apply to the senior management posts (heads of department and deputy municipal managers). It also resolved that an effective communication strategy be put in place to convey this policy to all affected and interested parties.

\section{Conclusion}

The heuristic continuum that was developed helped guide the review of Cape Town's appointment policy for senior staff. The Committee rejected the comprehensive patronage and fused party-state model on the basis that it would lead to large-scale purging which, in turn, would fundamentally undermine the administrative capacity of the Council. The medium patronage model was not formally considered by the Committee, although it was implicitly rejected because of similar concerns about capacity, albeit primarily at management level. The neutral 
model was explicitly rejected by the Committee because it reflected the naïve political-administration dichotomy.

The minimalist appointment model was the preferred option of the Committee. It would enable newly elected councils to choose certain strategic posts, while ensuring the continuity of the overwhelming majority of local government employees.

There are also comparative implications of the comparative continuum. It locates the notion of the neutral official at the one extreme of the continuum which correctly illustrates the untenability of the politics/administration model. For countries that still adhere to this model, they run the risk of ignoring the policy-making powers of officials and the potential of bureaucrats to usurp political leadership.

The advantage of the minimalist appointment models in ensuring both strategic opponents and staff continuity has already been discussed. It is suggested that this model has utility in local governments in both developed and developing countries. One problem is that even some local governments that use this model are not open about it and still theoretically at any rate, adhere to this fallacious notion of the neutral official.

Local governments that use or wish to use the minimalist appointment model need to be transparent about it. The important point that needs to be made to career officials is that the overwhelming majority of them would not be affected by the explicit adoption of this model.

This minimalist appointment model could be useful for countries wishing to move away from patronage or fused party-state models towards a more professional local government service but are concerned about the notion of a neutral and largely autonomous local government service. The fact that senior strategic positions are appointed by political leadership could make this model an attractive option for such countries.

\section{References}

Adamolekun, L. (1986) Politics and Administration in Nigeria. London: Spectrum.

Bole-Ntotele, B. (1986) 'Introduction to a Study of the Efficiency of Administrative Systems in Sub-Saharan Africa', International Review of Administrative Sciences 52(2): 173-85.

Byrne, T. (1986) Local Government in Britain, 4th edn. Middlesex: Penguin.

Cameron, R.G. (1986) 'The Administration and Politics of the Cape Town City Council', Unpublished M.Pub.Admin degree, University of Cape Town.

Cameron, R.G. (1996) 'The Democratisation of South African Local Government', Local Government Studies 22(1): 19-39.

Cameron, R.G. (2000) 'Megacities in South Africa: A Solution for the New Millennium?, Public Administration and Development 20(2): 155-65.

Cameron, R.G. (2001) 'Politics-Administration Interface at Local Government Level, Cape Town', Unpublished paper.

Campbell, A. (1995) 'Regional Power in the Russian Federation', in Coulson, A. (ed.) Local Government in Eastern Europe, pp. 145-67. Aldershot: Edward Elgar.

Cloete, F. (1995) Local Government Transformation in South Africa. Pretoria: J.L. van Schaik. 
Coetzee, R. (2001) 'Is It a Matter of Trust or Just a Witchhunt?', The Argus, 19 February.

Committee of Inquiry (2001) Independent Review Body into City of Cape Town's Interim Appointment Policy for Senior Officials, Cape Town.

Coulson, A. (ed.) (1995) Local Government in Eastern Europe. Aldershot: Edward Elgar.

Cox III, R.W., Buck, S.J. and Morgan, B.N. (1994) Public Administration in Theory and Practice. Engelwood Clifts, NJ: Prentice Hall.

Craythorne, D.L. (1990) Municipal Administration: A Handbook. Cape Town: Juta.

Democratic Alliance (2001) A Policy Approach to Political Appointments in DA Governments, Cape Town.

Gunlicks, A.B. (1986) Local Government in the Germany Federal Republic. Durham, NC: Duke University Press.

Halligan, J. (1997) 'Comparing Relations between Politicians and Public Servants in Anglo Systems: Transformation or Reaffirmation?', Paper presented at International Association of School and Institutes of Administration Annual Conference, Quebec, Canada.

Harris, P. (1990) Foundations of Public Administration. A Comparative Approach. Hong Kong: Hong Kong University Press.

John, P. and Cole, A. (1999) 'Political Leadership in the New Urban Governance: Britain and France Compared', Local Government Studies 25(4): 98-115.

Keating, M. and Hainsworth, P. (1986) Decentralisation and Change in Contemporary France. Aldershot: Gower.

Lipsky, M. (1980) Street Level Bureaucracy. New York: Russell Sage.

Mphaisha, C.J. (2000) 'Public Administration under the Kaunda Presidency in Zambia: 1964-1991', Administration Publica 10(1): 1-24.

Nickson, R.A. (1995) Local Government in Latin America. Boulder, CO: Lynne Rienner.

Norton, A. (1986) Local Government in other Western Democracies. The Future Role and Organization of Local Government. Introductory paper no. 4, Institute of Local Government Studies. Birmingham: University of Birmingham Press.

Peters, G.P. (1989) The Politics of Bureaucracy. White Plains, NY: Longman.

Republic of South Africa (1998) Local Government: Municipal Structures Act. Cape Town: Government Printer.

Smith, B.C. (1988) Bureaucracy and Political Power. Sussex: Wheatsheaf Books.

Subramaniam, A. (1977) 'Politicized Administration in Africa and Elsewhere. A Sociohistorical Analysis', International Review of Administrative Science 43(4): 297-308.

Subramaniam, V. (1990) Public Administration in the Third World. An International Handbook. New York: Greenwood Press.

Svara, J.H. (1985) 'Dichotomy and Duality. Deconceptualising the Relationship between Policy and Administration in Council-Manager Cities', Public Administration Review 45(1): 221-32.

Svara, J.H. (1998) 'The Politics-Administration Model as Aberration', Public Administration Review 58(1): 51-8.

Waldo, D. (1968) 'Public Administration', International Encyclopedia of Social Sciences, Vol. 13, pp. 145-56. New York: Crothier and Macmillan.

Wallis, M. (1989) Bureaucracy: Its Role in Third World Development. London: Macmillan.

Wilson, D. and Game, C. (1998) Local Government in the United Kingdom. Hampshire: Macmillan Press. 